\title{
Conceptualizing War via Cross-Domain Mapping in Julian Grenfell's Poem Into Battle
}

\author{
Rufaidah Kamal Abdulmajeed ${ }^{1} \&$ Lina Laith Younus ${ }^{1}$ \\ ${ }^{1}$ College of Education for Women, University of Baghdad, Iraq, Baghdad \\ Correspondence: Rufaidah Kamal Abdulmajeed, College of Education for Women, University of Baghdad, \\ Baghdad, Iraq. E-mail: hajeya2@gmail.com
}

Received: May 29, 2018

Accepted: June 25, 2018 Online Published: July 28, 2018

doi:10.5539/ijel.v8n6p88

URL: https://doi.org/10.5539/ijel.v8n6p88

\begin{abstract}
Metaphor is known for most people as a device of the poetic imagination and a matter of extraordinary rather than ordinary language. George Lakoff, (1992) claims that metaphor is fundamentally found in thoughts not in language. He defines metaphor as "a cross-domain mapping in the conceptual system", while the metaphorical language is "a surface manifestation of conceptual metaphor". This study deals with the war poem Into Battle of Jullian Grenfell as a sample of war poetry flourished during the First World War. The results show that the application of Lackoff's cross-domain mapping theory of metaphor functions as a way of a vital presentation of the images of war. By these metaphorical images, the war actions become easily comprehended by the readers who do not have a chance to live in or to participate in wars.
\end{abstract}

Keywords: war poetry, conceptual metaphor, George Lackoff, cross-domain mapping theory, Jullian Grenfell

\section{Introduction}

Metaphor means the transfer in the meaning of one expression and its application to another one. Aristotle sees that the metaphorical meaning is always the literal meaning of another expression from which the metaphorical one is derived. He regards the phenomenon of metaphor as a decorative device (Cruse, 2000, p. 202) and as a source of deception and untruthfulness.

This view of metaphor witnessed a turning point in the 1930s when Richards, 1936, p. 96) criticizes it. He defines metaphor as a matter of thought instead of language saying that what is found in language is simply the reflection of human thoughts. He defines metaphor as a process of borrowing and moving from one thought to another. He considers human thoughts as metaphoric in nature. These metaphoric thoughts are followed by a process of comparison which is reflected in language.

The classical theory of language sees metaphor as "a matter of language" that can be found only in literary work and has no place in everyday conventional language. It is known for most people as "a device of the poetic imagination and the rhetorical flourish - a matter of extraordinary rather than ordinary language" (Lakoff \& Johnson, 2003, p. 4).

In a further development in the 1980s, a great turning point happened in the field of metaphor study and research by Lakoff and Johnson (1980). In their book Metaphors We Live By, they propose "conceptual metaphor theory". They call this kind of metaphor as "Conceptual Metaphor". It operates on the level of thinking and linking the "source" domain and "target" domain. The "source" domains consists of literal entities called "lexical sets", stored in the mind, linked semantically and is expressed in language through words and expressions organized and related to each other as groups. The "target" domain is an abstract entity takes its structure from the "source" domain through the metaphorical link. The entities in the "target" domain are lexicalized by using words and expressions from the "source" domain. These words and expressions are called "linguistic metaphor" or "metaphorical expressions".

Lakoff (1992) claims that metaphor is fundamentally in thoughts not in language, and the use of metaphor is not limited to the literary and figurative language but it extends to the everyday conventional use of language. Metaphors are general mapping across conceptual domains. He defines metaphor as "a cross-domain mapping in the conceptual system", while the metaphorical language is "a surface manifestation of conceptual metaphor" (ibid., p. 1). 
This study deals primarily with the application of this theory on war poem of Julian Grenfell's Into Battle as a sample of war poetry. This poem will be the data of the analysis to find out how war images portray the actions of war in the battle field and how they are presented to the readers through metaphor to make them easily comprehended and imagined. The results show that using Lackoff's cross-domain mapping theory is applicable on war poetry to make the images of war conceptually available to every reader especially to those who haven't any chance to attend or to participate in wars.

\section{Lakoff's "Conceptual Metaphor"}

Using metaphors in the everyday language proves Lakoff \& Johnson's theory (1980) that metaphor is in the conceptual system of human minds. In terms of his theory, the phrase "cross-domain mapping" is known as a process of matching across different linguistic domains. In this process, the linguistic expressions (words, phrases, or sentences) are matched or moved from one source domain that is their normal context to the target domain that is the linguistic area in which the expressions will be used metaphorically.

Consequently, metaphor is characterized by a huge system of thousands of cross-domain mappings. This system is used in the novel and poetic metaphor to prove that the study of literary metaphor is just an extension of the study of everyday metaphor (Lakoff, 1992, p. 4). This will be clear if it is applied on Lakoff's example:

LOVE IS A JOURNEY. So, he regards journey or space as a source domain, while love will be the target domain. The process of mapping should be moved from the source domain space with all its properties to the target domain love. Thus, the love relationship will be the vehicle in which the lovers are traveling.

Lakoff (ibid.) depends on discovering how the use of metaphors is extended to include the everyday use of language and not be restricted to the literary use of language. This fact has its role to prove his idea that metaphor is in thoughts and what is found in language is only "the surface manifestation" of those metaphoric thoughts.

A very clear example of reflecting conceptual metaphor in our everyday language is:

\section{ARGUMENT IS WAR}

This example of conceptual metaphor is reflected in everyday language by a wide variety of expressions like:

- Your claims are indefensible.

- He attacked every weak point in my argument. His criticisms were right on target.

- I demolish his argument.

- I've never won an argument with him.

- You disagree? Okay, shoot.

- If you use that strategy, he'll wipe you out. He shot down all of my arguments. (Lakoff \& Johnson,1980, p. 5)

\section{Characteristics, Types and Ways of Understanding Metaphors}

\subsection{Systematicity of Metaphor}

Listing the above examples under the conceptual metaphor of ARGUMENT IS WAR proves the assumption of Lakoff that "the essence of metaphor is understanding and experiencing one kind of thing in terms of another" (ibid). So in the aforementioned examples argument is dealt with in terms of the concept of war. It is not an accident to use all of these vocabularies of war by chance like: attack a position, indefensible, strategy, new line of attack, win, gain ground etc... One way of understanding metaphor is by its systematicity. Lakoff found that metaphorical concept is systematic. Our thoughts are metaphorically systematic and work like network. This systematicity in metaphorical thoughts is reflected in language to be metaphorically systematic (ibid., p. 8).

Systematicity is concerned with highlighting one aspect of the metaphorical concept and hiding the other one. Systematicity comprehends the aspect of argument in terms of the battle and hides the cooperative aspect of argument in which speakers give each other time and a valuable commodity in order to reach a mutual understanding. Systematicity highlights the battle aspect of metaphor in which each speaker wants to win the argument by attacking his or her opponent's position and defending his or her own (ibid., p. 10).

\subsection{Orientation of Metaphor}

It is another kind of metaphorical concept that does not structure one concept in terms of another but "organizes the whole systems of concepts with respect to one another" (Lakoff \& Johnson, 2003, p. 15). Most of such metaphors have something to do with spatial orientation represented by the polar oppositions of: up-down, 
in-out, front-back, on-off, deep-shallow etc. This type of metaphor provides an extraordinary rich basis for understanding concepts in orientational terms. Thus, metaphorical orientations are not arbitrary. They depend on our physical and cultural experience (ibid.).

Here are some examples of orientation spatial metaphors are:

\section{HAPPY IS UP, SAD IS DOWN}

\section{HAPPY IS UP}

- I am feeling up.

- That boosted my spirits.

- My spirit rose.

- You are in high spirits.

- Thinking of her always gives me a lift.

\section{SAD IS DOWN}

- I'm depressed.

- He's really low these days.

- I fell into a depression.

- My spirits sank.

The physical basis for the above examples:

Orientational metaphors provide a concept with a spatial orientation that is to say HAPPY IS UP is derived from our physical body experience. Thus, the concept HAPPY is oriented UP. That comes from the erect posture which goes along with positive emotional state. As for the SAD IS DOWN depends on the physical basis of drooping posture that goes along with sadness and depression (ibid., p. 16).

In terms of the aforementioned example, Lakoff concludes that all orientational metaphors have spatial relationships with our fundamental concepts. Each spatialization metaphor has an internal and external systematicity. All of the spatial metaphors are rooted in our physical and cultural experience by which metaphor is seen as a vehicle to understand most of the concepts.

Cultural values are embedded in metaphors used by one society and coherent by its social members. So one way of understanding metaphorical concepts is by understanding the culture they belong to because cultural values are reflected on metaphors. Thus, the orientational metaphors front-back in one culture front conceptualizes better future (concept of progress) and back conceptualizes the past. But in another culture the other way around, the meaning is completely the opposite. e.g. "the future will be better" (Lakoff \& Johnson, 2003, p. 22). These values are not independent but they are part of coherent system with the metaphorical concepts we live by.

\subsection{Ontological Metaphors}

A further basis for understanding metaphor set by Lakoff and Johnson is Entity/Substances or what is named as Ontological metaphors. By which one can go beyond orientation in order to understand our experience or part of it and treat them as entities or substances of a uniform kind. Then, one can refer to them, categorize them, group them and quantify them. In this type of metaphor, the unphysical concepts are metaphorically viewed as entities or substances in order to meet humans' various purposes in life (Lakoff \& Johnson 2003, p. 26). Entities and substances can be referred to, quantified, identified to cover the following points below:

\section{Referring}

- My fear of insects is driving my wife crazy.

- That was a beautiful catch.

- We are working toward peace.

\section{Quantifying}

- It will take a lot of patience to finish this book.

- There is so much hatred in the world.

- DuPont has a lot of political power in Delaware. 


\section{Identifying Aspects}

- The ugly side of his personality comes out under pressure.

- I can't keep up with the pace of modern life.

- His emotional health has deteriorated recently.

\section{Identifying Causes}

- The pressure of his responsibilities caused his breakdown. He did it out of anger.

- Our influence in the world has declined because of our lack of moral fiber.

- Internal dissension cost them the pennant.

\section{Setting Goals and Motivating Actions}

- He went to New York to seek fame and fortune.

- Here's what you have to do to insure financial security. I'm changing my way of life so that I can find true happiness.

- The FBI will act quickly in the face of a threat to national security (ibid: 27).

\subsubsection{Container Metaphor}

Container is another basis for understanding metaphor. This type views any physical entity as a container. Things can be in or out of it in terms of in-out orientation. For example, our physical body is a container surrounded by our skin that separates it from the outside environment. This idea is clearly applied on the following example:

\section{VISUAL FIELDS ARE CONTAINERS}

- The ship is coming into view.

- I have him in sight.

- I can't see him - the tree is in the way. He's out of sight now.

In these examples, our visual field is conceptualized as a container and all other objects are either in or out of that vision. For example, the word "view" in the first sentence is a container into which the ship is coming (Lakoff \& Johnson 2003, p. 30).

Lakoff \& Johnson define this type of metaphor as "a natural one that emerges from the fact that, when you look at some territory (land, floor, space etc.), your field of vision defines a boundary of the territory, namely, the part that you can see" (ibid., p. 31). Thus, in terms of Lakoff \& Johnson's definition, any bounded physical space is regarded as a CONTAINER and all other things we can see in our FIELD OF VISION are parts of that container that emerges naturally to structure the metaphorical concept VISUAL FIELDS ARE CONTAINERS.

The same idea is applied on events, actions, activities and states like:

- The finish of the race was really exciting. (EVENT AS CONTAINER)

- There was a lot of good running in the race.(ACTIVITY AS CONTAINER)

- In washing the window, I splashed water all over the floor. How did Jerry get out of washing the windows? (ACTION AS CONTAINER)

- He's in love.

- We're out of trouble now.

- He's coming out of the coma. (STATE AS CONTAINER) (ibid: 32).

\subsubsection{Imageable Idioms}

Idioms are part of our everyday conventional language. In terms of the classical theories, idioms have arbitrary meanings. But the cognitive school of linguistics proves that the meanings of idioms are not arbitrary, they have productive rules to construct their structure. It is claimed that each idiom carries an image and associates this image with the real conventional images from our everyday life. These associated conventional images allow an independently- motivated conceptual metaphor to map that knowledge, experience or image from its source domain of the imageable idiom to the target domain of our real life experience. This will be more obvious in looking at the idiom "spinning one's wheels". This idiom carries a conventional mental image of the wheels of a 
car that are stuck in something either mud or snow. In this case, the car cannot move when the motor is engaged and the wheels turn. So there is a great energy without progress (Lakoff, 1992, p. 8).

Thus, to map this image from its source domain of a state of a car to the target domain of our real life images I can say: I am spinning my wheels in completing the school project (ibid). This means that I am not progressing or completing the school project in spite of the great effort spent on it. So here the image of a spinning car is mapped from the domain of cars to the domain of school work to structure imageable idiom metaphor.

\section{Novel or Poetic Metaphor}

In terms of the classical theory of metaphor, it is defined as "a novel or poetic linguistic expression where one or more words for a concept are used outside of its normal conventional meaning to express a similar concept" (Lakoff, 1992, p. 1). But in terms of Lakoff's contemporary theory, novel or poetic metaphor is an extension of everyday conventional metaphor. So, all of the aforementioned characteristics, types and ways of understanding conventional metaphors are also applied on the novel or poetic metaphors. In addition, here are some metaphorical types that are more common in the literary works rather than in conventional everyday language:

\subsection{Image Metaphors}

It is one of the poetic types of metaphors that have the function of mapping one conventional mental image onto another. The process of mapping here is different from the aforementioned types of metaphors. The image of metaphor is "one-shot metaphors" because they map one image onto another, whereas in all other types of metaphors many concepts are mapped from the source domain onto many corresponding concepts in the target domain (Lakoff, 1990, p. 25).

This poetic type is more common in poetry as in this line for (Andre Breton): "My wife ... whose waist is an hourglass" (ibid., p. 26). The poet here maps the image of an hourglass onto the image of his wife's waist by virtue of their common similar shape. So, metaphor is not based on words but on the mental images found in human mind and then reflected on language. Human match between the similarities in images seen in his surrounding and express them by language.

\subsection{Personification}

It is to see non-human things as human. It is to "comprehend a wide variety of experiences with non-human entities in terms of human motivations, characteristics and activities" (Lakoff \& Johnson, 2003, p. 33). It is clear in the following examples:

- Our biggest enemy right now is inflation.

- The dollar has been destroyed by inflation.

- Inflation has robbed me of my savings (ibid.).

The conceptual metaphor here is INFLATION IS A PERSON. "Inflation" is personified to be our enemy has the ability to destroy and can rob our savings. Lakoff claims that such kind of metaphor is a general category that underlies a very wide range of metaphors. He prefers to be much more specific to modify the inflation metaphor into INFLATION IS AN ADVERSARY. This will be a very specific way of thinking of inflation (Lakoff, 1992, p. 27).

In poetry, the personification is a very common type of metaphor. Let's take the concept of "Death" and how it is conceptualized in the poems. Death is always personified as "driver, coachmen, reaper, devourer, destroyer or opponent in game". All of those are examined to fit different shapes of the same sort of actions. Lakoff takes this example to hypothesize a very general metaphor EVENTS ARE ACTIONS. For example the concept of death is personified as DEATH IS DEPARTURE then we can consider "departure" as an event caused by an action performed by a person.

\subsection{Metonymy}

It is a class of metaphor in which we are "using one entity to refer to another that is related to it" (Lakoff \& Johnson, 2003, p. 39). It is used when an expression refers to an actual person or something related to him like his (writings, wearing, painting etc.). In personification we are not referring to an actual person. The concept of "inflation" is personified to have some qualities of a person but there is no actual person to refer to. On the other hand, metonymic concept allows to "conceptualize one thing by means of its relation to something else" (ibid.). Let's consider this example: "He likes to read the Marquis de Sade"; here there is no space for personification because we are referring to the writings of that actual person "Marquis de Sade" (ibid., p. 36). 
The metonymic concepts are also systematic because they are classified under a number of metaphoric cases represented by the following example:

- THE PART FOR THE WHOLE

We need a couple of strong bodies for our team. (= strong people)

There are a lot of good heads in the university. (= intelligent people)

- PRODUCER FOR PRODUCT

He bought $\boldsymbol{a}$ Ford.

He's got a Picasso in his den. I hate to read Heidegger.

- OBJECT USED FOR USER

The sax has the flu today.

The $\boldsymbol{B} \boldsymbol{L} \boldsymbol{T}$ is a lousy tipper.

- INSTITUTION FOR PEOPLE RESPONSIBLE

Exxon has raised its prices again.

You'll never get the university to agree to that.

- THE PLACE FOR THE INSTITUTION

The White House isn't saying anything.

Washington is insensitive to the needs of the people.

- $\quad$ THE PLACE FOR THE EVENT

Pearl Harbor still has an effect on our foreign policy.

It's been Grand Central Station here all day (ibid: 38-39).

\section{War Poetry}

War poetry as a literary trend; perhaps a genre developed with the enormous impact of the great modern wars of the twentieth century, is mainly associated with the young soldier-poets who came to fame during and after the First World War. However, it is largely presented in literature in different directions globally throughout and after the great wars of the violent century. War poetry's main association with war-poets is ultimately related to their first-hand war front experience, and refers to their actual presence in battlefields and combat actions. In other directions war poetry is articulated realistically through the written representation of many civilian writers caught up by war in other ways. Paul Fussell in his literary account of war literature The Great War and Modern Memory (1975) points out that war literature is an "Inquiry into the Curious literariness of Real life" and present it as a proper subtitle to his war literature presentation throughout the twentieth century (Fussell, 1975, p. ix). Hence war poetry is a representation of life; that happens to be a cruel one. However; war poetry did not only articulate anti-war spirit but was directed by propaganda. The subversive war poetry; intensively proposed the questions of "identity, innocence, guilt, loyalty, courage, compassion, humanity, duty, desire and death" (War Poet Association: online). War poetry written during and after the war was not isolated from the century's literary outrage and cultural turmoil. Poetry like the poets attends the war frontlines articulating new concepts and shocks the traditional artistic and aesthetic presentations of their familiar techniques and enriched poetic language with new metaphors. It is celebrated largely later in the century in criticism and cultural comprehension as a true historical account of the violent combat and civilian experience of the modern technological wars.

The poetry assigned with the horrors of the great wars broke new grounds and gave realistic account of the warfare through actual vocabulary, literary devices and formal poetic innovations. Despite the undeniable expression of courage and the soldiers' sacrifice of precious lives on the altar of wars for the defense of their countries, however wars are no longer presented as a "glorious" account of this sacrifice but a "piteous" reality; in Wilfred Owen's words in his 1918 preface.

\section{Julian Grenfell and His Poem Into Battle}

Julian Grenfell is an English poet. From childhood, he wrote poems about nature towards which he had a deeply-felt response. He graduated from Oxford in 1910 and joined the Royal Dragoons. By 1914, he was to leave the army but the war was declared on $4^{\text {th }}$ August and by early October, Grenfell was in France. "He loved the outdoor life, the companionship of horses, dogs and men and the opportunity to throw himself into the fight for a noble cause. Later he was promoted to the rank of Captain" (War poet association: online). 
He thought that going to war is a glory to him. He wrote his famous letter to his family saying that "I adore war. It is like a big picnic without the objectivelessness of a picnic. I have never been more well or more happy." These words prove that he enjoyed being in the battlefield fighting for the sake of glorious life that he loved. On $13^{\text {th }}$ May 1915, Grenfell was wounded and he died on 26th May. Into Battle was published in "The Times" together with the announcement of his death.

His best poem Into Battle was written during the First World War. It is one of the finest lyrics of the Great War. He wrote it when he was waiting to move to the front, in praise of war and the soldier fighting in this war. "It expresses his long-felt, almost mystical connection with the natural world and the fighting man's place within it" (ibid.). It has a strong pastoral feel as many other poems which were very concerned with the countryside and rural life. Therefore, nature was a source of inspiration for him. The birds and trees and even the army horses around the poet are teaching the soldier how to live and at the same time prepare for death. In this poem, "Grenfell's soldier follows the classical ideal of the soldier, who looks to gain glory through battle" (Move Him Into The Sun: on-line).

The structure of the poem consists of 10 stanzas, simple classic rhyme scheme, 4 line verse i.e. quatrain of 8 syllables each, rhyming as cross-rhyme ABAB.

\section{The Model of the Analysis}

Lakoff's (1992) "Conceptual Metaphor" theory will be the model of the analysis of the poem. The analysis will make a link between the "source" and the "target" domain. The "target" domain consists of an abstract entity that takes its structure from the "source" domain through the metaphorical link. The entities in the "target" domain are lexicalized by using words and expressions from the "source" domain. The conceptual process of bringing the meaning from its source domain into a target domain in which it appears to have near and similar meaning is called a cross-domain mapping.

\section{The Analysis of Data}

\section{Into Battle'}

(1) The naked earth is warm with spring,

And with green grass and (2) bursting trees

Leans to the sun's gaze glorying,

And quivers in the loving breeze;

The metaphoric image in (1) is a kind of personification. It is to see the "earth" which is non-human things as human. The source domain is lexicalized by the word "naked" as it is usually used to describe human beings. This word is metaphorically used to describe, the target domain "earth". The linking between the two domains is that the "stripped" appearance and uncovered objects.

The metaphoric image in (2) is lexicalized by the words "leans", "glorying", and "quivers". It is also a kind of personification. These words in the source domain are used to describe human beings. A person leans, glorifies and quivers. These words are stored in the minds and linked with human beings. The target domain is that these bursting trees lean on the sun's gaze and glorify and quiver because of the sunny breeze. The meaning in the source domain is moved to the target domain and linked semantically to give an image of a person leans in glory but at the same time quivers.

\section{And (3) life is Colour and Warmth and Light,}

And a striving evermore for these;

And he is dead who will not fight;

And who dies fighting has increase.

The metaphoric image in (3) is in the lexical entities "life", "colour", "warmth", and "light". The meaning of these words is moved from the source domain to the target domain. Life is shown here as a portrait with colours. The semantic linking is that life consists of different colours; in other words, it consists of sadness and happiness; warmth and light are for the sake of them a person strives.

The fighting man shall from the sun

Take warmth, and life from the glowing earth;

Speed with the light-foot winds to run, 
And with the trees a newer birth;

And find, when fighting shall be done,

Great rest, and fullness after dearth.

All the bright company of Heaven

Hold him in their high comradeship-

The Dog-star, and the Sisters Seven,

Orion's Belt and sworded hip.

The woodland (4) trees that stand together,

They stand to him each one a friend;

They gently speak in the windy weather;

They guide to valley and ridge's end.

The metaphoric image in (4) is lexicalized in the source domain by the word "trees", "stand", and "together". The image is that the trees stand one by one in the woodland. The target domain is lexicalized by the words "gently speak", "speak", and "guide". The metaphor here is the trees stand together as if they were friends of the poet. They speak gently and guide to the valley and the ridge's end. The trees do not speak and do not guide. The personification of the trees is done by using the verbs "speak" and "guide". The meaning is that trees are friends who speak gently in the windy weather, i.e. the war.

The kestrel hovering by day,

And the little (5) owls that call by night,

Bid him be swift and keen as they-

As keen of sound, as swift of sight.

The metaphoric image in (5) is also a kind of personification. The owls do not "call" and "bid". These are verbs are used for personal activities not for non-personal creatures. The lexical items "call", "bid", and "keen" are moving the image from the sources domain which is human activity to the target domain which is the owls' actions.

The blackbird sings to him, "Brother, brother,

If this be the last song you shall sing,

Sing well, for you will not sing another;

Brother, sing."

In (6) dreary doubtful waiting hours,

Before the brazen frenzy starts,

The (7) horses show him nobler powers;

O patient eyes, courageous hearts!

The metaphoric image in (6) is lexicalized in the words elements "dreary", "doubtful", "waiting". The poet personifies the entity of "hours" by bringing the human characteristics of waiting and having sad feeling to the hours reflecting the time of war that people usually feel sad because time is too long and they have to wait for the end of sadness.

The image metaphor (7) is lexicalized in the words "show", "nobler", "patient", and "courageous hearts". The personification in this image is clear. The horses are described with human characteristics. The verb "show" is an action performed by a person and the words "nobler", "patient", and "courageous" are human characteristics. The source domain characteristics are moved to be part of the target's domain merits. The poet wants to portrait the horses, as he does with other creatures in the previous stanzas, behaving in a nobler way towards the fighting man and having courageous hearts with patient eyes. The horses here stand and behave as friends of the fighting man who devote themselves for the sake of friendship.

And when (8) the burning moment breaks,

And all things else are out of mind,

And only (9) Joy of Battle takes 
Him by the throat, and makes him blind-

The lexical items in image (8) are "burning" and "breaks". They are used metaphorically to describe an action done by the "moment". The source domain of "burning" refers to that there is something tangible burning and not this abstract reference. The moment does not burn but the poet tends to portrait a real image of a battle field and how the moment the war launched is like some glass items are broken.

The lexical items in (9) "takes him by throat" and "makes" are personifying the "joy". Joy never takes and makes. These verbs are used metaphorically to move the source domain's characteristics to the target domain. Joy of battle is portrayed as a man taking other one from his throat to make a determined attempt to deal with the moment of launching the war and thus he becomes blind.

Through joy and blindness he shall know,

Not caring much to know, that still

Nor lead nor steel shall reach him, so

That it be not the Destined Will.

The (10) thundering line of battle stands,

And in the air (11) death moans and sings;

But (12) Day shall clasp him with strong hands,

And (13) Night shall fold him in soft wings.

The personification is a very clear metaphor in (10). The metaphoric images are lexicalized in words items "line", "stands". The thundering line of battle stands as human being. The metaphoric image in (11) is lexicalized in the words "death", "moans", "sings". The concept of "death" is conceptualized in this poem. Death is personified as human who moans and sings. The concept of death is personified as human who takes actions and performs human activities. Metaphor (12) is lexicalized by the words items "day", "clasp", "strong hands". The concept of day is also personified as a man who clasps the fighting man with strong hands. Metaphor (13) is finally lexicalized by the words "night", "fold", and "soft wings". Night is also personified as a person who folds the fighting man with soft wings. The activities and the characteristics of the human source domain are moved and attached to non-human concepts in the target domain.

\section{Results and Discussion}

The results of the analysis show that the poet tends to use metaphor in a very wide range. He uses thirteen metaphorical images. The dominant metaphoric type is personification; to see non-human things as human. There are wide variety of experiences with non-human entities in terms of human motivations, characteristics and activities. The reason behind that is that the scene of war is not familiar to normal people who haven't a chance to participate in any war or to be a soldier in an army. The poet graphs the scenes of the war by using personification to make these scenes nearer to the mind of the reader and easy to comprehend what is going on in the battle field.

Using metaphor as one of the rhetoric devices to accomplish persuasion is the poet's main aim and goal. He thinks that going to war is a joyful event. He adores war and, in the battle field, he imagines himself as if he is in a picnic and free from panic and fear. He is happy and he enjoys every moment there and wishes others to be with him to gain a glorious life that he loves.

With these aims and intentions he wrote this poem and in order to reflect his enjoyment in the battle field, he intentionally uses a large number of metaphoric images to transfer to the reader how the war is and how beautiful scenes he is seeing and what a glorious life he is living at that moment.

Thus, metaphor is used to transfer the war images to the hearer/reader minds to make them easier to be imagined and nearer to the minds of the recipients. He does so by conceptualizing the war through the cross-domain mapping device and by extending the meaning from the human domain to non-human domain. This device is the most prominent way to envisage the unknown imaginary thoughts and make them visible in the eyes of the readers. By following this notion, the poet is successful in bringing the images of war up to the mind of the reader in a very easily comprehended image. 


\section{Conclusion}

The occurrence of words with extended or transferred meaning is called a figurative shift which makes it possible to give a language element another semantic function than that directly associated with its primary sense. This kind of language is chiefly concerned with the shift in the meaning of words.

Metaphor is fundamentally one type of shift in meaning of words. It is in thoughts not in language, and what is found in language as metaphor is only the derivation from those metaphoric thoughts. It is quite clear that metaphor is a figure of speech containing an implied comparison. It is a comparison between a word or a phrase in its ordinary usage and its application to another. It suggests that the two dissimilar things in situations are the same.

Vital presentation of war images requires a cross-domain mapping analysis of metaphors. Metaphors are fundamentally in thoughts and then extended to be reflected on language. The results show that human conceptual process of bringing the meaning from its source domain into a target domain in which it appears to have near and similar meaning to perform a cross-domain mapping is widely used in the Grenfell's poem In Battle. War is mapped from its source domain bringing all its properties and semantic field and personified onto the human activities.

\section{References}

Cruse A. (2000). Meaning in Language: An Introduction to Semantics and Pragmatics. Oxford: Oxford University Press.

Fussell, P. (1975). The Great War and Modern Memory. London: Oxford University Press.

Lakoff, G. (1992). The Contemporary Theory of Metaphor. Cambridge: Cambridge University Press.

Lakoff, G., \& Johnson, M. (1980). Metaphors We Live By. Chicago: University of Chicago Press.

Lakoff, G., \& Johnson, M. (2003). Metaphors We Live By. Chicago: University of Chicago Press. https://doi.org/10.7208/chicago/9780226470993.001.0001

Move Him Into The Sun. (2017). Retrieved from https://movehimintothesun.wordpress.com/2010/11/22/into-battle-julian-grenfell/

Richards, I. A. (1936). The Philosophy of Rhetoric. Oxford, Oxford University Press.

War poet association. (2017). Retrieved from http://www.warpoets.org/poets/julian-grenfell-1888-1915/

\section{Copyrights}

Copyright for this article is retained by the author, with first publication rights granted to the journal.

This is an open-access article distributed under the terms and conditions of the Creative Commons Attribution license (http://creativecommons.org/licenses/by/4.0/). 